\title{
Identification and Collection of Macro Fungi (Basidiomycota: Agaricales) From Baturraden Botanical Garden, Banyumas
}

\author{
Dhea R. R. Edyawati ${ }^{1}$, Nuniek Ina Ratnaningtyas ${ }^{1}$, AtikRetnowati ${ }^{2}$ \\ ${ }^{1}$ Faculty of Biology Jenderal Soedirman University \\ ${ }^{2}$ Biology Research Center, Indonesian Institute of Sciences \\ e-mail: dhea.edyawati@gmail.com
}

\begin{abstract}
Article Hostory:
Received : 27/08/2019

Accepted : 21/10/2019
\end{abstract}

\begin{abstract}
Agaricales is a group of macrofungi which comprises of many edible and poisonous members. Agaricales is characterized by having a fruiting body that is fleshy in some species and few species are not fleshy, lamellae, and stipe. The group usually grows well in quite moist areas and it cannot be found in dry conditions. The Indonesian Agaricales has not been intensively studied and there is still very few information on its diversity. While in fact, the diversity of Indonesian Agaricales is high due suitable environment and humidity for these fungi to grow. However, there are only a few species that have been identified. Under the circumstances above, this research is aimed to identify the Indonesian Agaricales, particularly from Baturraden Botanical Garden, Banyumas, Central Java and to collect the specimens as dry herbarium. The research involved collection, description, identification, preservation, and documentation of specimens, and the method used a survey with purposive random sampling. The collected Agaricales were identified by using both macromorphological and micromorphological characters. The macromorphological characters as shape, size, color, margin, surface, the flesh of the pileus, lamellae, and stipe were examined. The micromorphological characters as spores and the basidium were examined. Nine specimens had been collected in Baturraden Botanical Garden and were identified to 6 genera that belong to 4 families and 2 unidentified species, namely Hydropus sp., Mycena sp., Panellus sp., Psathyrella sp., Simocybe sp., DRRE 002, DRRE 010.

Keywords: Agaricales fungi, Banyumas, Baturraden Botanical Garden, collection, identification
\end{abstract}

\section{INTRODUCTION}

Indonesia is the third largest tropical rainforest in the world after Brazil and Congo. It has variety of coastal ecosystems, lands to highlands or mountains. Tropical rainforest is a home to a variety of flora and fauna species including fungi, and the fungi is the second largest diversity after insects. The number of fungal species that has been found is \pm 69.000 from the estimated 1.500.000 species of fungi in the world. According to the humid forest environment and tropical temperatures that support fungal growth, so that Indonesia has a very high fungi diversity (Wahyudi et al., 2016). As a country that has extensive tropical rainforests with high species diversity of macro fungi, research on the diversity of macro fungi has not been widely done in Indonesia. Until now the data and literature on the diversity of macro fungi in Indonesia are still very limited. The available data and literature on macro fungi are generally about fungi in subtropical climates that obviously have different colors, shapes, sizes, and species with macro fungi in tropical climates. The diversity of ecosystems in tropical forests caused by different geographical conditions causes a variety of species diversity within them (Firdhausi \& Basah, 2018).
Fungi are important natural resources in the forest and for human life. Ecologically, fungi play a role in ecological events such as their association with trees in the nutrient cycle, food webs and significantly affect the survival of tree growth and overall forest activities. The role of fungi is an important indicator of dynamic forest communities. Fungi are well known in everyday life, although not as popular as plants. This is because fungi only can be found at certain times and conditions, with a limited place to grow and life span. Fungi grow a lot during rainy season on weathered wood, litter, or haystacks. But fungi will most likely die in the dry season.

Macro fungi or also known as mushroom is characterized by having a large fruit body that can be observed directly. Generally, its fruit body, particularly, Agaricales, looks like an umbrella (Achmad et al., 2011). Mushroom can be seen with the naked eye, held or picked by hand, and has the pierce shape. The fruiting body of Basidiomycota phylum have various shapes and colors such as bright red, bright brown, orange, white, yellow, cream and even black (Gandjar et al., 2006). Meanwhile, the shape of mushroom fruiting body generally in the form of umbrellas, bowl, ear, semicircular and round shaped. Mushroom also characterized by having pseudo-roots (rhizoids), stems 
(stipe), cap (pileus), blades (lamellae/gills), and sometimes accompanied by rings (annulus/ring) and cup (volva) (Yunida \& Yeni, 2014).

The existence of many flora in Baturraden Botanical Garden provides habitat for other organisms, including fungi. Information about Agaricales fungi in Baturraden Botanical Garden is not yet available although the natural condition of Baturraden Botanical Garden supported the growth of Agaricales. The research focuses on the inventory, identification, and collection of Agaricales is necessarily conducted, in specific inquiries of what genera that can be identified and collected. The collection will improve the quantity of Herbarium Bogoriense (BO) fungal collections and will be beneficial for further research related to Agaricales fungi species in Baturraden Botanical Garden.

This research were proposed to solve two problems as to : how many Agaricales species can be found in Baturraden Botanical Garden and what genera they belong. The objectives of this research were: 1) To identify Agaricales fungi from Baturraden Botanical Garden, Banyumas; 2) To collect dry specimens of Agaricales fungi as herbarium.

\section{MATERIAL AND METHODS}

The sampling technique used a survey with purposive random sampling method. It took place randomly in Baturraden Botanical Garden by exploring the areas. The description of macro-morphology characters, such as the upper part of pileus including shape, color, canopy width, and surface texture. The lower part of pileus including apparatus basidium (the lamellae attachment to stipe, lamellae color, and the lamellae space distance). The characters of stipe included shape, diameter, color, length, the presence of annulus, rigorous of pileus, and the color changes after picking and fresh condition based on fungi identification book.

Microscopic characteristic observation was done after drying process. Fungi specimen then covered with cover glass and then the microscopic character such as spores and basidia was observed under the microscope. Identification process was done by comparing the morphological data to the described species which is published in HowtoIdentify Mushroom to Genus VI: Modern Genera book.Data of The morphological data and specimen collection that have been gain was being analyzed descriptively.

\section{RESULTS AND DISCUSSION}

Based on the results of sampling and identification of Agaricales fungi in Baturraden Botanical Garden, Banyumas, nine specimens had been collected and identified as six genera belonged to 4 families and two unidentified species(Table 1).

The results showed that family Tricholomataceae are the most common mushrooms found. Three species of Tricholomataceae were collected in Baturraden Botanical Garden, this mushroom can be easily found because it can grow in various habitat (Sari et al., 2015). According to (Darwis et al., 2009), several types of Tricholomataceae mushrooms can be found in trees and wood, swamps, soil or grassland.

Table 1. List of Encountered Agaricales in Baturraden Botanical Garden

\begin{tabular}{llll}
\hline \multicolumn{1}{c}{ Species } & \multicolumn{1}{c}{ Family } & \multicolumn{1}{c}{ Grow Habit } & \multicolumn{1}{c}{ Substrate } \\
\hline Hydropus sp. & Tricholomataceae & Scattered & Decaying wood \\
Mycena sp. & Tricholomataceae & Gregarious & Decaying wood \\
Panellus $\mathrm{sp}$. & Tricholomataceae & Solitary & Wood \\
Psathyrella $\mathrm{sp}$. & Coprinaceae & Gregarious & Decaying wood \\
Simocybe $\mathrm{sp}$. & Cortinariaceae & Gregarious & Soil \\
Termitomyces sp. & Lyophyllaceae & Solitary & Soil \\
DRRE 002 & - & Solitary & Soil \\
DRRE 010 & - & Solitary & Wood \\
\hline
\end{tabular}

\section{Family Tricholomataceae}

\section{Hydropus sp.}

Pileus $1.8 \mathrm{~cm}$; uplifted; dimidate; crenate; shiny; moist; rivulose; latex presence; dark brown. Gills adnate; close (24 attached lamellae) with 4-6 series of lamellulae; broad; wavy. Stipe 1.4 x $0.4 \mathrm{~cm}$; lateral; terete; equal; longitudinal striate; woody; solid; veil absence; volva absence; whitish.

Basidiospores whitish. Basidia unobserved. Basidioles unobserved. Hyphae 14.8-22.1 $\mu \mathrm{m}$, dextrinoid. Cystidia absent.

\section{Mycena sp.}

Pileus from $0.8-1.6 \mathrm{~cm}$ diam; convex to campanulate; shallowly depressed; round; undulating; decurved; shiny; moist; rivulose; surface glabrous; latex absence; peach to pink. Gills adnate; subdistant (20 attached lamellae) with 3-5 series of lamellulae; moderately broad; crenate. Stipe from 1.3-2.2 x 0.1-0.3 $\mathrm{cm}$; central; equal; terete; longitudinal striate; fibrous; solid; veil absence; volva absence; light peach to pink. 
Basidiospores 2.5-10 x 5-10 $\mu \mathrm{m}$; whitish; globose. Basidia unobserved. Basidioles unobserved. Hyphae 2.5-7.4 $\mu \mathrm{m}$, dextrinoid. Cystidia absent.

\section{Panellus sp.}

Pileus $2.6 \mathrm{~cm}$ diam; dimidate; crisped; shiny; moist; smooth; surface glabrous; latex absence; brown. Gills free; crowded (42 attached lamellae) with 6 series of lamelullae; narrow; crisped. Stipe 0.3 x $0.3 \mathrm{~cm}$; lateral; compressed; equal; longitudinal striate; woody; solid; veils absence; volva absence; whitish.

Basidiospores 2.5-7.4 x 9.8-52 $\mu \mathrm{m}$; whitish. Basidia unobserved. Basidioles unobserved. Hyphae 2.5-5 $\mu \mathrm{m}$, dextrinoid. Cystidia absent.

\section{Family Coprinaceae Psathyrella sp.}

Pileus $0.9-1.6 \mathrm{~cm}$ diam; campanulate to convex during immature stage, became expanded convex to plane in age; surface glabrous; crenate; appendiculate; dull; moist; rivulose; latex absence; dull brown. Gills decurved; crowded (20-35 attached lamellae) with 7 series of lamellulae; ventricose; crisped. Stipe 1.7-3.2 x 0.2-0.3 cm; central; terete; equal; longitudinal striate; cartilaginous; solid; veil absence; volva absence; light brown.

Basidiospores 5 × $7.4 \mu \mathrm{m}$; brownish; bacilliform. Basidia unobserved. Basidioles unobserved. Hyphae 7.4-19.7 $\mu \mathrm{m}$, non-dextrinoid. Cystidia absent.

\section{Family Cortinariaceae}

\section{Simocybe sp.}

Pileus from 1.3-2.1 cm; conic; round; crisped; decurved; dull; dry; rivulose; surface glabrous; latex absence; dark brown. Gills adnate; close (36 attached lamellae) with 3 series of lamellulae; ventricose;crisped. Stipe from 0.8-4.0 x 0.2-0.3 cm; central; terete; equal; longitudinal striate;cartilaginous; solid; veil absence; volva absence; light brown. Gregarious.

Basidiospores 5-7.4 x 2.5-7.4 $\mu \mathrm{m}$; brownish; oblong. Basidia unobserved. Basidioles unobserved. Hyphae 5-12.3 $\mu \mathrm{m}$, dextrinoid. Cystidia unobserved.

\section{Family Lyophyllaceae}

\section{Termitomyces sp.}

Pileus $18.8 \mathrm{~cm}$ broad; broadly umbonate; fan shaped; appendiculate; dull; dry; rivulose; surface glabrous; latex present; light brown. Gills adnexed; crowded (120 attached lamellae) with 1 series of lamellulae; moderately broad; off white; eroded. Stipe 19.5 x1.3 cm; central; terete; equal; punctate; fibrous; solid; veil absence; volva absence; brown and white.

Basidiospores 2.5-7.4 x 2.5-7.4 $\mu \mathrm{m}$; whitish; sublobose. Basidia unobserved. Basidioles unobserved. Hyphae 7.4-12.3 $\mu \mathrm{m}$, dextrinoid. Cystidia absent.

\section{Unidentified \\ DRRE 002}

Pileus $2.5 \mathrm{~cm}$ diam; convex to campanulate; round; crisped; decurved; dull; dry; rivoluse; surface glabrous; latex absence; brown. Gills free; close (52 attached lamellae) with 3 series lamellulae; dark brown; narrow; crisped. Stipe 1.6 x $0.2 \mathrm{~cm}$; central; terete; equal; longitudinal striate; cartilaginous; solid; veil absence; volva absence; brown.

Basidiospores 2.5-7.4 x 2.5-7.4 $\mu \mathrm{m}$; brownish; oblong. Basidia unobserved. Basidioles unobserved. Hyphae 5-12.3 $\mu \mathrm{m}$, non-dextrinoid. Cystidia absent.

\section{DRRE 010}

Pileus from 0.2-1.2 cm diam; convex during immature stage; fan-shaped in age; crisped; shiny; dry; smooth; surface glabrous; latex absence; brown. Gills adnexed; crowded (42 attached lamellae) with 6 series of lamelullae; narrow; crisped.Stipe 1.0 x $0.6 \mathrm{~cm}$; lateral; compressed; equal with bulbous; longitudinal striate; woody; solid; veils absence; volva absence; whitish.

Basidiospores unobserved. Basidia unobserved. Basidioles unobserved. Hyphae 5-7.4 $\mu \mathrm{m}$, dextrinoid. Cystidia absent.

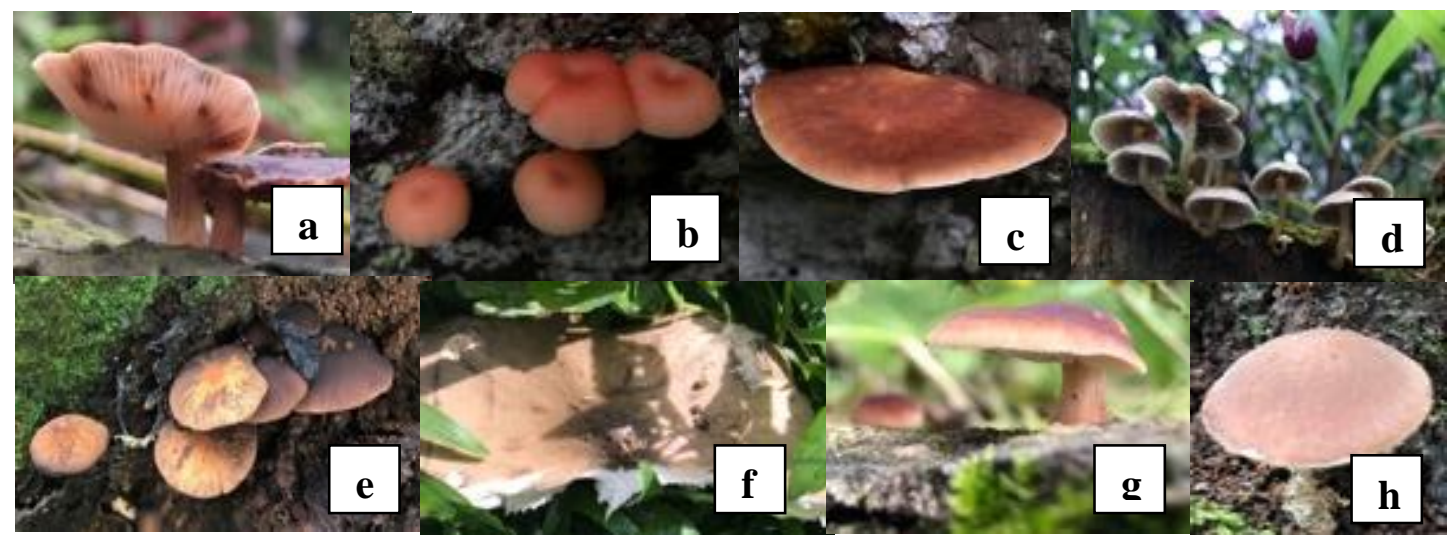

Figure 1. Figures of encountered Agaricales fungi in Baturraden Botanical Garden: (a) Hydropus sp. (b) Mycena sp. (c) Panellus sp. (d) Psathyrella sp., (e) Simocybe sp. (f) Termitomyces sp. (g) (h) unidentified. 
The abundance of fungi is correlated with environmental factors surrounding the area. Environmental factors are important for the fungi to grow. Suitable environmental factors will help fungi to grow well in the nature. According to Proborini (2012), the growth of fruiting bodies and the spread of fungi from Basidiomycota are strongly influenced by environmental factors, such as temperature, humidity, altitude and rainfall. The spores of fungi can be optimally distributed by air or it owns substrate even though each type of fungi has a certain and different temperature range. In humid soils, hyphae are able to grow and develop well. The environmental factors that has been obtained from three times sampling process showed the similar result.

Table 2. Data of Environmental Factors in Baturraden Botanical Garden

\begin{tabular}{cccc}
\hline Environmental Factors & \multicolumn{3}{c}{ Measurement Result } \\
\cline { 2 - 4 } & $\mathbf{1}^{\text {st }}$ Sampling & $\mathbf{2}^{\text {nd }}$ Sampling & $\mathbf{3}^{\text {rd }}$ Sampling \\
\hline Temperature & 25 & 24 & 24 \\
Humidity & $85 \%$ & $87 \%$ & $87 \%$ \\
Soil pH & 6.6 & 7 & 7 \\
\hline
\end{tabular}

Table2. shows the result data of environmental factors in Baturraden Botanical Garden. The result of temperature and humidity in Baturraden Botanical Garden are around $24^{\circ} \mathrm{C}-25^{\circ} \mathrm{C}$ for temperature and $85-$ $87 \%$ for humidity. According to Arif et al. (2007), the optimum temperature for fungi growth is $22-35^{\circ} \mathrm{C}$, meanwhile, the humidity range that suitable for fungi to grow at a range of $70-90 \%$ (Sari et al., 2015). The fungi that has been found in the Baturraden Botanical Garden is mesophilic fungi. Mesophilic fungi is a type of fungi that grows at a temperature range of $25^{\circ} \mathrm{C}$ $37^{\circ} \mathrm{C}$ (Sopialena et al., 2018). The condition of temperature is quite low and has relatively high humidity in Baturraden Botanical Garden region because the research was carried out during rainy season. According to Proborini (2012), low temperature, high humidity, and nutrition are one of the main requirements for the growth of fungi. In addition

\section{REFERENCES}

Achmad, Mugiono, Arlianti \& Azmi, 2011. Panduan Lengkap Jamur. Depok: Penerbit Swadaya.

Arini, D. I. D. \& Christita, M., 2016. Keanekaragaman Makrofungi di Cagar Alam Gunung Ambang Sulawesi Utara dan Peluang Potensinya. Proceeding Seminar Nasional Biodiversitas VI, pp. 49-59.

Firdhausi, N. F. \& Basah, A. W. M., 2018. Inventarisasi Jamur Makroskopis Di Kawasan Hutan Mbeji Lereng Gunung Anjasmoro. Jurnal Biology Science \& Education, 7(2), pp. 142-146.

Gandjar, I., Sjamsuridzal, W. \& Oetari, A., 2006. Mikologi Dasar dan Terapan. Jakarta: Yayasan Obor Indonesia.

Gardner, F. P., Peaece, R. B. \& Mitchel, R. L., 1991. Fisiologi Tanaman Budidaya. Jakarta: UI Press.

Kramadibrata, K., 2017. Keanekaragaman Gloromycota di Kebun Raya Baturraden dan Sekitarnya di Gunung Slamet. Berita Biologi, 12(2), pp. 217-222. to temperature and humidity, $\mathrm{pH}$ is also an important factor for fungi growth because $\mathrm{pH}$ is influential in terms of providing nutrients for fungi. The results of $\mathrm{pH}$ measurements from each sampling process ranged from 6.6-7. The result of $\mathrm{pH}$ measurement is in accordance with Gardner et al. (1991) statement that most nutrient for fungi growth is available in $\mathrm{pH}$ between 6-7.

\section{CONCLUSION}

Nine specimens have been collected from Baturraden Botanical Garden and were identified as six genera belonged to 4 families and 2 unidentified species, namelyHydropus sp., Mycena sp., Panellus sp., Psathyrella sp., Simocybe sp., Termitomyces sp., DRRE 002, DRRE 010.

Proborini, M. W., 2012. Eksplorasi dan Identifikasi Jenis-Jenis Jamur Klas Basidiomycetes di Kawasan Bukit Jimbaran Bali. Jurnal Biologi, XVI(2), pp. 45-47.

Sari, I. M., Linda, R. \& Khotimah, S., 2015. Jenis-Jenis Jamur Basidiomycetes di Hutan Bukit Beluan Kecamatan Hulu Gurung Kabupaten Kapuas Hulu. Protobiont, 4(1), pp. 22-28.

Sopialena, N., Akhsan, A. \& Suryadi, J. N., 2018. The identification of soil fungi isolated from rhizosphere in different varieties of jali (Coix lacryma-jobi) in Loa Kulu, Kutai Kartanegara, Indonesia. Asian Journal of Agriculture, 2(2), pp. 44-47.

Sumarni, S., Angking, Y. \& H, R. R., 2017. Identifikasi Jenis Jamur Makroskopis Di Kawasan Hutan Lindung Bukit Rentap Desa Ensaid Panjang Kecamatan Kelam Permai Kabupaten Sintang. Publikasi Informasi Pertanian, 25(13), pp. 148163. 
Wahyudi, T. R., Rahayu, S. \& Azwin, 2016. Keanekaragaman Jamur Basidiomycota di Hutan Tropis Dataran Rendah Sumatera, Indonesia (Studi Kasus di Arboretum Fakultas Kehutanan Universitas Lancang Kuning Pekanbaru). Jurnal Kehutanan, 11(2), pp. 22-23.
Yunida, N. \& Yeni, L. F., 2014. Inventarisasi Jamur di Gunung Senujuh Kabupaten Sambas dan Implementasinya Dalam Pembuatan Flash Card. Jurnal Pendidikan dan Pembelajaran, 3(10), pp. 1-16. 